Bond University

Research Repository

\title{
Designing games to motivate student cohorts through targeted game genre selection
}

De Byl, Penny Baillie; Brand, Jeffrey E.

Published in:

Handbook of research on improving learning and motivation through educational games: Multidisciplinary approaches

DOI:

10.4018/978-1-60960-495-0.ch027

Licence:

Other

Link to output in Bond University research repository.

Recommended citation(APA):

De Byl, P. B., \& Brand, J. E. (2011). Designing games to motivate student cohorts through targeted game genre selection. In P. Felicia (Ed.), Handbook of research on improving learning and motivation through educational games: Multidisciplinary approaches (pp. 567-582). IGI Global. https://doi.org/10.4018/978-1-60960-495-0.ch027

\footnotetext{
General rights

Copyright and moral rights for the publications made accessible in the public portal are retained by the authors and/or other copyright owners and it is a condition of accessing publications that users recognise and abide by the legal requirements associated with these rights.
}

For more information, or if you believe that this document breaches copyright, please contact the Bond University research repository coordinator. 


\title{
Chapter 27 \\ Designing Games to Motivate Student Cohorts through Targeted Game Genre Selection
}

\author{
Penny de Byl \\ Bond University, Australia \\ Jeffrey E. Brand \\ Bond University, Australia
}

\begin{abstract}
The objective of this chapter is to develop guidelines for targeted use of games in educational settings by presenting a typology of learning styles, motivations, game genres, and learning outcomes within disciplinary student cohorts. By identifying which academic outcomes best align with the motivations and learning styles of students and which game genres are best suited to those motivations and outcomes, the authors elucidate a typology to assist serious game designers' and educators' pursuits of games that both engage and instruct. The result will guide the implementation of games in the classroom by linking game genre and game mechanics with learning objectives, and therefore enhance learning and maximise education outcomes through targeted activity.
\end{abstract}

\section{GAMES AS MOTIVATORS}

The notion of using games as motivators to facilitate learning is a key driver for the design of Serious Games, as computer games inherently motivate players to meet their objectives (Malone, 1981; Malone \& Lepper, 1987; Tychsen, Hitchens et al., 2008). Research has shown that the use of games in the classroom improves student motivation (Baltra, 1990; Gee, 2007) and participation

DOI: 10.4018/978-1-60960-495-0.ch027
(McGonigal, 2007; Rigby \& Prysbylski, 2009; Werner, Hanks et al., 2004). Moreover, different game genres (Wolf \& Baer, 2002) have been found to be effective for different types of learning (Garris, Ahlers et al., 2002) and may work for different personality types (Rapeepisarn, Wong et al., 2008).

Despite the evidence that learning styles, motivation, personality and game genre are diverse, Serious Games tend to be used in the classroom with a one-size fits all approach. This is understandable because games development is 
expensive and resource-intensive to develop. As such, creating different games for a single type of player to meet the needs of all learning styles would be an unsustainable commercial model. A more targeted approach would be to consider the learning styles of a particular student cohort based on field of study and assessment types and develop and select games which are most effective in meeting their learning objectives. For example, engineering students likely have a common learning style (c.f., Feldman, 1974) in which the average differs from that of media students; law students must learn laws and policies which require memorization and questioning learning activities as opposed to psychology students who learn about behavior through interviews, coaching and practice.

\section{LEARNING ACTIVITIES AND LINKS TO GAME MECHANICS}

Differing experiential learning methods are applied across different professions and academic disciplines in higher education. From empirical evidence, Kolb and others (Kolb, 1981; Honey \& Mumford, 1982; Kolb \& Kolb, 2005) have discovered that broadly speaking:

- $\quad$ practitioners of creative disciplines, such as the arts, have a "try it and see" attitude towards learning and prefer to innovatively experiment to see how and if things work;
- pure scientists and mathematicians are best at processing abstract ideas and prefer problem-solving activities;

- $\quad$ applied scientists prefer to use a scientific approach to solve practical problems while lawyers respect scientific evidence; and

- professionals who have to operate more intuitively, such as teachers, prefer learning situations in which they are required to take risks and partake in new experiences.

In addition, Prensky (Prensky, 2005) recognises the need to deliver educational content and assessment with differing game genres and mechanics because different types of content and learning require different pedagogical approaches. Some examples are given in Table 1.

This chapter is designed to better connect the heretofore disjointed dots from literature on learning through games, motivation, educational activities, and personality psychology. It begins by examining learning style and how it affects the suitability of learning activities across disciplines. Following this, personality types across the student cohort will be investigated as this too has been linked with learning style, discipline and game genre choice and links learning and motivation in a critical relationship that also focuses attention on learning objects and learning environments, such as games. Next, the concept of motivation is discussed with respect to the most effective ways to stimulate disciplinary specific student cohorts to engage with their educational content. Motivation will also be explored with respect to

Table 1. Educational content associated learning activities and games. Extracted from Prensky (2005)

\begin{tabular}{|c|l|l|l|}
\hline Content & \multicolumn{1}{|c|}{ Examples } & \multicolumn{1}{c|}{ Learning Activities } & \multicolumn{1}{c|}{ Games } \\
\hline Facts & $\begin{array}{l}\text { Laws, procedures, product specifications, } \\
\text { policies, chemical elements }\end{array}$ & $\begin{array}{l}\text { Questions, practice and drill, memo- } \\
\text { risation }\end{array}$ & Flash cards, Detective Games \\
\hline Language & Acronyms, foreign languages & Imitation, immersion, practice & $\begin{array}{l}\text { Role playing Games, Flash cards, Simu- } \\
\text { lation Games }\end{array}$ \\
\hline Creativity & Invention, product design & play & Puzzles, Invention Games \\
\hline
\end{tabular}


learning styles and personality traits. These will be used later in the chapter to match suitable game mechanics to study domains. After this, an elucidation of game genre and mechanics will be provided to explain the learning opportunities available in action games, adventure games, strategy games and process-orientated games. Finally, a typology will be presented which provides clear guidelines for matching disciplinary student groups with the most appropriate types of games for delivering educational content relevant to their vocation.

\section{LEARNING STYLES}

Learning style refers to the way a student processes information. They are often referenced with respect to how different learning and teaching approaches motivate different students. One of the most frequently cited models based on Experiential Learning Theory (ELT) is Kolb's (1981) research on learning styles and Kolb and Kolb's (2005) Learning Style Inventory (LSI). The inventory has evolved since it was introduced in the early 1970s, based on repeated trials with different large samples drawn from a wide range of different populations.

Another and related model of four learning styles provides a simplified structure to understand learners' approaches to acquiring and using new information (Busato, Prins et al., 2000) and these are predictably covariate with personality traits. The first learning style is undirected in which learners struggle to process study information, manage the volume of information and fail to prioritise important information and filter out unimportant information. Reproduction directed students are instrumentalists who reproduce content to pass examinations. Application directed students attempt to apply new information to real-world settings and their own experiences. The last learning style is meaning directed in which students seek to analyse new information to form their own view and definitions or applications while allowing for critical rejection of some or all of the information they are given. In this section we posit the ways in which different learners, perhaps in different discipline cohorts (Brauer \& Delemeester, 2001) likely learn from computer games generally and we base this analysis on Kolb and Kolb (2005) who note, “...previous research with the LSI shows that student learning style distributions differ significantly by academic fields, as predicted by ELT," (p. 26).

\section{The Learning Style Inventory}

The LSI examines strengths and weaknesses of a learner based on experiential learning theory. Experiential learning is considered a four-stage cycle for (1) immediate concrete experience; (2) observation and reflection; (3) formation of abstract concepts and generalisations; and (4) testing hypotheses to create new experiences. Thus, the effective learner possesses four different learning modes: Concrete Experience (CE), Reflective Observation (RO), Abstract Conceptualization (AC), and Active Experimentation (AE). This means, they must be able to involve themselves fully, openly, and without prejudice in novel experiences (CE), reflect on and notice these experiences from multiple perspectives (RO), create concepts that link observations with logically sound ideas (AC), and use these ideas in decision making and problem solving (AE). The extent to which a student engages with these learning modes determines their learning styles; Diverger, Assimilator, Converger or Accomodator. For each style, researchers Honey and Mumford (1982) recommend different teaching methods that best suit these classifications.

\section{Divergers}

Divergers are reflective learners. They learn best by listening and sharing ideas. They are imaginative and insightful thinkers. The strengths of these 
students include innovative and creative work, perceptive thinking, ability to function in a team environment as well as alone and the ability to analyse problems from different perspectives. Recommended careers for divergers mostly focus on working with people in occupations such as teachers, counselors or public relations.

These students learn best in situations when they can observe others at work and review conditions of that work. Accordingly, comparative analysis and other types of reports are the preferred types of assignment. However, these reflective learners do not respond well to tight deadlines, role-playing and being thrown in at the deep end.

\section{Assimilators}

Assimilators are theorists. As learners, they excel at processing abstract ideas such as those presented in mathematics and the sciences. They prefer to think through ideas and to solve problems rationally with sequential thinking and detailed information. These types fit well in occupations involving natural science, mathematics and research.

Theorists benefit the most from teaching and learning exercises when they are put in situations that require them to use their knowledge and skills to solve complex problems. They prefer structured instruction which can be linked to their specific interests and learning objectives. In addition, these types of learners excel at discovering the reasoning behind ideas. They like to know how things work. Less popular with these types of students are emotional situations, unstructured lessons, incomplete information and being asked to complete a task without knowing the whole picture.

\section{Convergers}

Convergers are pragmatists. They learn through testing theories and applying common sense to real world problems. They have a practical approach to problem solving and prefer to use scientific evidence and facts. They dislike imprecision or extravagance. Occupations that would suit them include engineering, surveying and applied sciences.

Pragmatists prefer learning about topics, that help them achieve their goals. They do not shy away from role-playing and possess a need to learn through mimicking either role models or the work of others. They are less interested in learning about things that they cannot see have an immediate benefit to themselves personally and have no previously devised set of guidelines.

\section{Accommodators}

Accommodators are activists in that they learn by doing, through the experimentation of trial and error. They excel at taking risks, being flexible and self-discovery. They are energetic and good at engaging and motivating others. Accommodators are highly suited for careers in marketing, sales, education and professions involving the community.

These activists' paramount learning experiences lie in being involved in new experiences, problem-solving and experiential opportunities. They particularly enjoy working with others and being faced with difficult tasks. These types of learners prefer to be leading discussions in class and directing other students in problem solving tasks. To best accommodate these types, lectures, long reading and writing exercises and precise instructive tasks should be avoided.

\section{Learning Styles and Academic Discipline Relationships}

There have been many studies performed within educational institutions to determine if learning styles differ among academic discipline (Biglan, 1973; Feldman, 1974; Kolb \& Kolb, 2005; Vermunt, 2005; Lindblom-Ylanne, Trigwell et al., 2006). Significant variation has been found as shown in Figure 1. For example, Business stu- 
Designing Games to Motivate Student Cohorts through Targeted Game Genre Selection

Figure 1. Learning style differences among academic disciplines adapted from Biglan 1973, Feldman 1974, Kolb 1981 and de Byl 2010

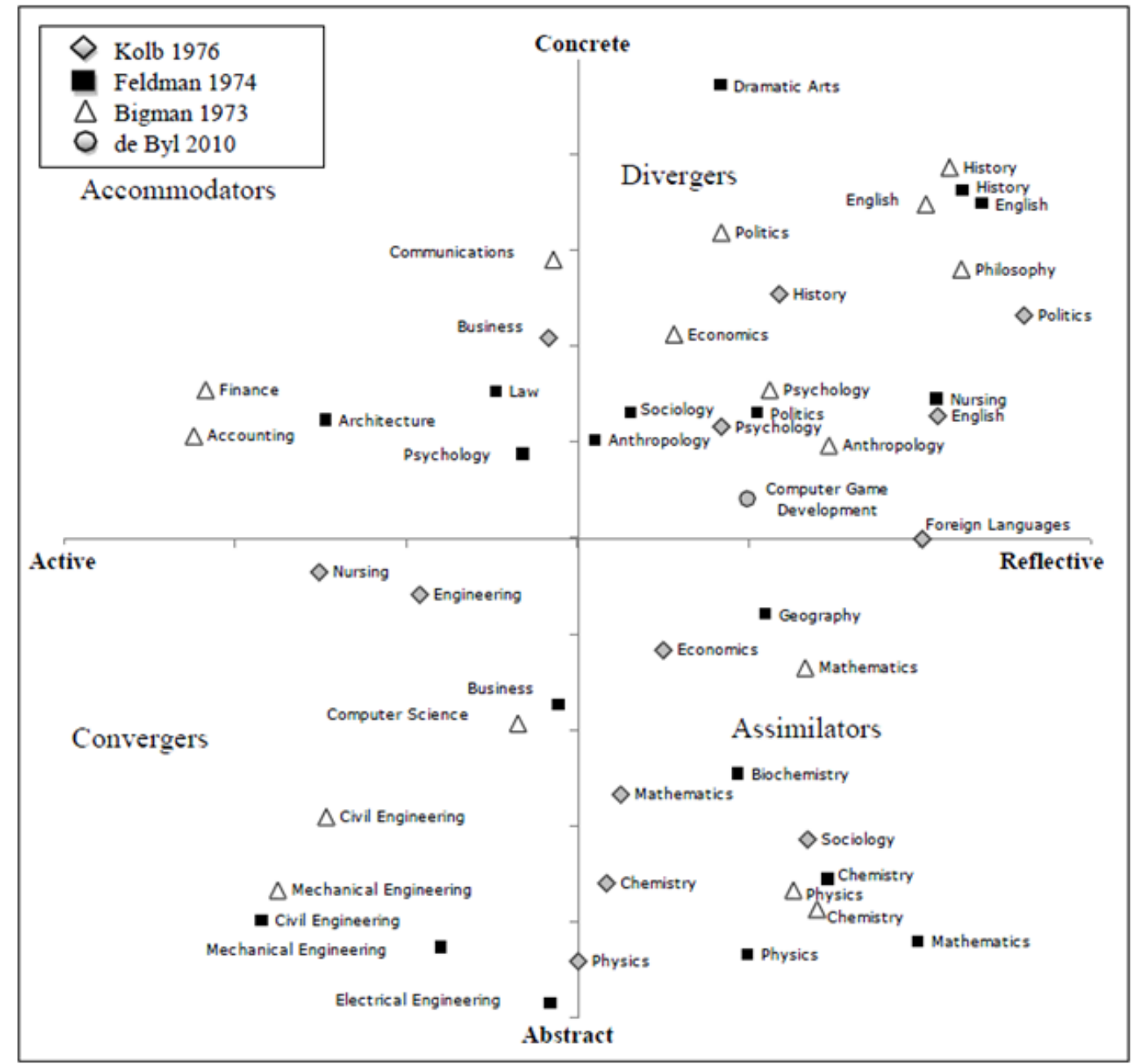

dents were observed by Feldman (1974) and Kolb (1976) at different ends of the Abstract-Concrete dimension of learning with Feldman observing them as more Concrete learners and Kolb finding Business students tending toward Abstract learners. However, Feldman (1974) and Kolb (1976) observed business students at the same position on the Active-Reflective dimension of learning with both observing them to balance Reflective and Active. This suggests that more variables need to be considered to understanding of how different people learn. For example, at the individual level, personality factors are implicit in the four studies represented in Figure 1. At a broader level divergent outcomes in these studies are explained by definitions of disciplines which vary among educational institutions and discipline boundaries where some fields may naturally represent a more diverse range of knowledge domains (for example, Business compared with Chemistry).

This information is being used by many educators to design curriculum and teaching activities which best fit their students' learning styles to enhance academic performance. Rather than a 
one size fits all approach or a customised and personalised approach through use of analysis of student cohorts within disciplines, educators can better spend their time developing and delivering targeted teaching and learning activities which best suit their students needs.

\section{Educational Implications for Learning Styles and Motivating Students with Games}

In recent years Serious Games have become more accepted in the classroom. The initial assumption being that because students find games engaging, an educational game should be an effective way of learning. Serious Games, however, deliver interaction and educational content in many and varied ways (as discussed later in the chapter). Of course, the game format might not suit all students. In addition, different types of learning content are better delivered with certain game mechanics than others. For example, Prensky (2005) suggests facts learned through questioning, memorisation and drilling are best delivered in game show competitions and flashcard type games. Furthermore, the player's interaction and experience with a game environment differs according to their learning style (Chong, Wong et al. 2005). For example, Chong et al. found Convergers to dislike playing Counter Strike while Accommodators enjoyed it and Assimilators did not like puzzle games while Convergers thrived on them.

Educators who consider the learning styles of their students may implement more effective teaching methodologies which are more studentcentred than traditional methods. These different approaches to learning naturally are likely to depend too on personality differences which also relate to individual learning styles. A relationship among these factors may allow serious game designers to predict the way learners react and feel in different gaming situations.

\section{PERSONALITY FACTORS}

Personality is thought to underpin much of the cognitive functioning of learners (Busato, Prins et al. 2000). The most universally demonstrated and simplistic structure for personality traits is widely described as "the Big Five" validated by Goldberg (Goldberg, 1990). Also known as the five-factor approach (FFA), these five factors are orthogonal to one another, meaning that each one is a continuum of low to high for every individual. The five factors are openness, conscientiousness, extraversion, agreeableness, and neuroticism. The first three are most commonly associated with learning motivation (Busato, Prins et al., 2000) and neuroticism being least associated with generalised learning motivations.

Importantly, these five factors are associated in different ways when compared with other social phenomena and not all parallel particular learning styles. A number of researchers have linked personality factors with learning styles (Kolb, 1981; Busato, Prins et al., 2000), motivation and achievement (Goldberg, 1990), and performance (Garris, Ahlers et al. 2002; Hu, 2004). Thus personality factors may link learning and motivation in a critical, but complex, relationship that also focuses attention on learning objects and learning environments, such as games and their many genres.

\section{Openness}

Having a higher level (or measured score) on openness has been related to being curious, imaginative, autonomous, and unconventional. At the level of face validity, an open personality would be naturally pre-disposed to the diverse worlds of computer games and particularly those that have a more exploratory and open objective structure. Learning in such an environment would be guided by those environments that present a sense of mystery and allow for free-form exploration. Busato et al. (1999) found that openness 
correlated positively with meaning and application directed learning styles and related these to Honey and Mumford's (1982) learning styles of activists and pragmatists and Kolb's (1981) corresponding learning styles accommodators and Convergers.

\section{Conscientiousness}

People who score highly on conscientiousness are associated with being dependable, having self-discipline, being planners, holding a sense of duty, and being achievement-oriented. For conscientious learner-players, games that are "on rails" and present the player with clear and defined achievement objectives would be best suited. Moreover, games with frequent reward schedules and competitive scoring ladders would likely appeal. Conscientious personality traits correlate positively with meaning, reproduction and application directed learning style according to Busato et al. (1999) and therefore Kolb's (1981) Accommodator.

\section{Extraversion}

High scorers on the extraversion personality dimension tend to be sociable, demonstrate positive attitudes and enthusiasm and are willing to assert their interests in the presence of others. Therefore, multiplayer, competitive and cooperative games would presumably be most effective in contributing to learning outcomes and motivation. Busato et al. (1999) found that extraversion correlated positively with meaning directed, reproduction directed and application directed learning styles on a par with Converger and Accommodators, but noted that it correlated negatively with the Reflector/Diverger learning style.

\section{Agreeableness}

Agreeableness is related to trusting others, being cooperative, even acquiescent, gentle and nurturing. As gamers, agreeable learners are likely to enjoy role-playing games, cooperative play and non-combat simulations. Busato et al. (1999) reported positive correlations between agreeableness and reproduction and application directed learning styles and the accommodator/ activist learning style.

\section{Neuroticism}

Those who score high on the dimension of neuroticism tend to display negative affects such as hostility and anxiety and are least likely to adjust easily to wide-ranging situations. Although neuroticism can be seen as a pejorative and maladaptive personality trait, one expects that games offering routine problem-solving, reality-based simulations and puzzles would appeal to such personalities. Neuroticism correlates negatively with Assimilator and Accommodator learning styles and positively with Diverger/Reflector learning styles (Busato et al., 1999).

The literature provides sufficient evidence of a non-linear relationship between learning style and personality trait. Indeed, Busato et al., (1999) have suggested only modest utility from measuring both learning style and personality trait. However, for the purposes of this typology, we suggest retaining the Big Five personality traits for explanatory and heuristic value in better understanding how to design serious games for different learners. Moreover, because learning style fails to account for all the variance observed in personality trait measures, we understand that designers will likely be able to predict game success by considering the multiple dimensions of their student audience. Game developers already identify player types in relation to game objectives (Bartle, 2005). However, research is needed particularly in the context of serious games to test different ludic dimensions (c.f., Aarseth, Smedstad \& Sunnana, 2003) of games (including objectives) with personality types identified by Goldberg (1990) and may need to include motivations for learning. 


\section{MOTIVATIONS}

Encouraging student motivation is an age old challenge for educators. While most students are inherently eager to learn many others require external stimulation from their teachers. The reaction to Prensky's "Digital Natives" description (Prensky 2000) has seen many educators challenge traditional teaching methods and has them scrambling to design, develop and integrate the latest technologies into the classroom in unconventional ways. Because students today demand more from their educational experiences than flat pages of content, noninteractive videos and text based communication software, materials deemed acceptable in the past now fail to engage students who are more attuned to the high quality 3D entertainment software such as computer games.

Although many educators and game developers have assumed computer games to be motivational for learning and teaching, because in general many students spend a lot of time playing computers games, this in itself does not guarantee games will produce the same level of motivation and engagement in the classroom. Studies have found that some individuals do not necessarily find educational games to be motivational even within the key demographic of game players (Whitton, 2007). This may be due to poor design or more importantly because the game genre and mechanics don't speak to the player.
Many factors influence individual student motivation. These include an interest in the subject matter, perception of topic relevance, a desire to perform well, patience and persistence. Furthermore students are motivated by a variety of diverse values, needs and desires. Fortunately, research has revealed correlations between motivational factors and learning styles across disciplines.

According to Shih and Gamon (2001), motivation is related to a student's learning style and influences their engagement, cognitive processing habits and metacognitive skills. Kellar, Watters et al. (2005) suggest a framework of positive and negative motivational factors in educational situations which includes:

- Control: the level of a student's autonomy within an environment which allows for interaction, innovation, personalization and decision making;

- Context: the relevance, completeness and believability of feedback and storylines,

- Competency: the provision and attainability of appropriate tasks and problem solving challenges; and,

- Engagement: the level of immersion within an activity given social interactions, methods of communication and rewards.

These factors when cross referenced with the pedagogical approaches given by Honey and

Table 2. Suggested pedagogical approaches for motivating students based on learning style

\begin{tabular}{|c|c|c|c|c|}
\hline & Divergers & Assimilators & Convergers & Accommodators \\
\hline Control & $\begin{array}{l}\text { High level of control over } \\
\text { environment to personalise } \\
\text { and innovate. }\end{array}$ & $\begin{array}{l}\text { Highly pre-defined and struc- } \\
\text { tured lessons. }\end{array}$ & $\begin{array}{l}\text { High control over manipula- } \\
\text { tion of environment in order } \\
\text { to test hypotheses }\end{array}$ & $\begin{array}{l}\text { Require an environment } \\
\text { where they can trial ideas and } \\
\text { learn from mistakes }\end{array}$ \\
\hline Context & $\begin{array}{l}\text { Observation and Reviewing } \\
\text { of Others }\end{array}$ & $\begin{array}{l}\text { Require holistic view of learn- } \\
\text { ing situation(e.g. all the facts). } \\
\text { Abstract problems }\end{array}$ & Relevant real world problems & $\begin{array}{l}\text { New opportunities, highly } \\
\text { challenging tasks }\end{array}$ \\
\hline Competency & $\begin{array}{l}\text { Approaching problem-solv- } \\
\text { ing from multiple perspec- } \\
\text { tives. }\end{array}$ & $\begin{array}{l}\text { Solving problems requiring } \\
\text { sequential thinking. }\end{array}$ & Mimicking & Risk-taking, Flexible \\
\hline Engagement & Team environments. & $\begin{array}{l}\text { Rational situations, work- } \\
\text { ing alone }\end{array}$ & Role-playing with others. & $\begin{array}{l}\text { Engaging with and leading } \\
\text { others }\end{array}$ \\
\hline
\end{tabular}


Mumford 1982 for each of Kolb's four learning styles produces the matrix of appropriate motivating pedagogical approaches for differing student cohorts shown in Table 2.

Computer games inherently address each of these factors. The degree to which they achieve these for an individual influences the learner's motivation to continue playing the game. Rather than considering how motivated a particular student group is towards their chosen areas of expertise, we should investigate what it is about the individual disciplines, their educational content and the way they are taught which produce this motivation. Moreover, research is necessary to better understand how games within particular genres can be designed to meet a wide range of motivations.

Mass entertainment games have large audiences because they match a wide range of motivators. The challenge for serious games is to embody a range of motivators that address all people from a disciple. Only then can we design targeted serious games which address student's learning needs.

\section{GAME GENRE}

Rapeepisarn et al (2008) argue that genres within educational computer games may present an important set of considerations for game designers. Early work in this area began in earnest by Papert in his work on Mindstorms (Papert, 1980) in which he considered children's developmental stages and therefore different processing routes for learning. He wrote,

... the computer can concretize (and personalize) the formal... it is not just another powerful educational tool. It is unique in providing us with the means for addressing ... the obstacle which is overcome in the passage from child to adult thinking. ... it can allow us to shift the boundary separating concrete and formal. Knowledge that was accessible only through formal processes can now be approached concretely. And the real magic comes from the fact that this knowledge includes those elements one needs to become a formal thinker. (p. 21).

Indeed, the intersection of learning styles, personality factors and motivations may well be concretised in player attachments to particular game genres. Although many observers value the utility of categorizing games (and other media) by genre, agreement on genres for games has not been easy. Wolf (2002) was among the first to give the matter detailed academic attention and he observed, "The idea of genres has not been without difficulties, such as defining what exactly constitutes a genre, overlaps between genres, and the fact that genres are always in flux..." (p. 113). The interactive nature of games has added a layer of complexity on top of the common elements that have characterized mainstream commercial cinema including formal features, story structure and theme. As genre is meant to provide a simple structure, the intersection between traditional genre elements and interactivity has made the formulation of genres for games more complex. Wolf, for example, concluded with 42 genre labels, one of which was educational. Wolfacknowledged the limitations of this unwieldy list observing that not all his labels represented mutually exclusive outcomes and noting that among the labels were applications that were not, strictly speaking, games. Yet Wolf's contribution borrowed from and has contributed to the commercial industrial labels often associated with game publishers' labels and those used by games reviews and journalism.

Subsequent research has refined and simplified the list of genres for game. Parsimony is essential in applying game genres to learning from games, particularly when cross tabulating these with other factors such as learning style, personality and motivation.

A simplified system of four genres based on a game's criteria for success such as that proposed 
Designing Games to Motivate Student Cohorts through Targeted Game Genre Selection

Table 3. Game genres, actions and success. Adapted from Egenfeldt-Nielsen et al. (2008)

\begin{tabular}{|c|l|l|l|l|}
\hline & \multicolumn{1}{|c|}{ Action games } & \multicolumn{1}{c|}{ Adventure games } & \multicolumn{1}{c|}{ Strategy games } & Process-oriented games \\
\hline $\begin{array}{c}\text { Typical action } \\
\text { (interactivity) }\end{array}$ & Battle & Solving mystery & $\begin{array}{l}\text { Build nation in competition } \\
\text { with others }\end{array}$ & Exploration and/ormastery \\
\hline Criterion of success & Fast reflexes & Logic ability & $\begin{array}{l}\text { Analysing interdependent } \\
\text { variables }\end{array}$ & $\begin{array}{l}\text { Varies widely, often non- } \\
\text { existent }\end{array}$ \\
\hline Sub-genres & $\begin{array}{l}\text { FPS, Combat, Race, } \\
\text { Rhythm }\end{array}$ & $\begin{array}{l}\text { Platformer, Flyers, Puzzle, } \\
\text { Quiz }\end{array}$ & $\begin{array}{l}\text { RTS, Gambling, Board, } \\
\text { Card, }\end{array}$ & Sims, RPG, MMORPG \\
\hline Archetypal titles & Counter-Srike & Myst & Civilization & Sim-City \\
\hline
\end{tabular}

by Egenfeldt-Nielsen, et al. (2008) fits well in the context of games for learning in which action, thinking and systemic understanding are clear goals aligned with learning styles. After we consider these four over-arching genres, we will then further align them with commonly understood genres along the lines of Wolf (2002) and commercial game publishing.

The criterion for a success model proposed by Egenfeldt-Nielsen at al. (2008) embeds within it Wolf's observation that games add to traditional media of cinema and television the element of interactivity. Thus, in addition to identifying a criterion for success, the model also accounts for the "typical action" a player performs in order to achieve success. For simplicity, we will focus on one discipline, health science, to demonstrate.

\section{Action}

The first of the four genres is action games in which "motor skill and hand-eye coordination" are essential in order to achieve success which is determined by the criterion of employing fast reflexes. Thus, for laparoscopic surgeons, superior motor skill and shorter surgical times have been linked with playing action games (Rosser, Lynch et al. 2007).

\section{Adventure}

Adventure games require "deep thinking and great patience," often found in solving mysteries or complex puzzles (c.f., Egenfeldt-Nielsen et al., 2008). The application of logic and clear thinking determines how a player succeeds in adventure games. Keeping with the theme of educating medical students, general practice is a panoptic field requiring investigation-based evaluation of patient presentations. An adventure inside the blood stream looking for pathogens attacking healthy cells would be consistent with this genre.

\section{Strategy}

Strategy games typically engage players in building nations or empires. They succeed at this by managing "large numbers of interdependent variables" and balancing a range of competing priorities. In medicine, the management of large patient caseloads, particularly in hospital wards might be well suited. Rather than seeking to train surgeons or oncologists, strategy games might be ideally suited to training hospital administrators and managers.

\section{Process-Oriented}

Finally process-oriented games centre on exploration of vast environments and even mastery of a detailed environment. By offering the player "a system to play with" growing skill and understanding, indeed mastering the complexities of the system or interface, is the criterion for success. In the early stages of medical education, a processoriented game would suit anatomy, developing 
knowledge of complex organs and coming to understand the inter-relationships among different systems. Table 3 shows the relationship between the four-genre structure and interactivity and success.

Kolb's (1981) learning styles focus on process (activity) and outcomes (success). EgenfeldtNielsen et al.'s (2008) genre classes, based on activity and outcomes provides a symmetrical heuristic with which to begin understanding the place of serious games in learning.

\section{PUTTING IT ALL TOGETHER}

Learning styles, personality factors, motivations and game genres are four fundamental elements that we propose make up a model for informed educational game design. In much the same way as commercial entertainment game designers target specific audiences with their products, serious game designers are able to use a relatively simple and yet highly predictive model by which to target student cohorts, particularly within disciplines, by matching game genres to learning styles, personality factors and motivations underlying specific learning objectives. For example, Nursing students might have an Active/Concrete (CE/ AE) Converger learning style. When they need to learn mathematics for nursing the type of game most appropriate (e.g. role playing/hospital simulation as opposed to other forms of learning mathematics (for example by rote). Concretely, time trials might work well with nursing where a drug dose has to be delivered within a timeframe ... for 12 patients at once!... but would work very poorly in a job that requires meticulous problem solving such as Human Resource Management in which puzzles might better suit. Thus, we are differentiating game play factors from game genres. Meanwhile, a deeply narrative game might be better for ethics training than time-management training because stories may be needed to express dilemmas, present context and consequences of actions along a story arc.

\section{Student Gaming Motivations Matrix}

Table 4 includes a summary of the information presented in this chapter matching learning style, disciplines, personality and learning motivators with suitable game genres. The variables considered in this chapter, summarized in Table 4 represent orthogonal combinations that require further investigation. Indeed, each combination deserves more detailed treatment than we present here. Borrowing from cognitive psychology and using this matrix as a heuristic, further research will likely produce better understanding for both educators and developers.

For example, cognitive psychology refers to a strategy for information recoding in short-term memory as chunking. Chase and Simon (1973) extended the use of the concept to indicate units of perception and meaning as long-term memory structures. In general, the term chunking has come to be understood as a learning mechanism. Miller (1956) found that people can hold $7+/-2$ chunks of knowledge in their minds at any given time. If the chunks simply contain unrelated facts, the knowledge obtained is restricted compared to chunks of interconnected facts. Domain experts chunk information to find meaningful patterns within a problem space. This concept is recognized across multiple areas of expertise (DeGroot, 1965; Egan \& Schwartz, 1979; Lesgold, 1988).

Learning researchers are increasingly making the same distinction in teaching and learning environments. Where rote memorisation techniques deliver disconnected chunks, chunks connected and organized around a concept provide a deeper level of understanding and the potential to transfer to other knowledge areas (Bransford et al., 2009).

This notion is at the very heart of the effective use of computer games for education. Games have the potential to provide learning in a meaningful context in which players learn to recognise inter- 
Table 4. Guideline for development of serious games for specific learning styles(*Honey and Mumford 1982)

\begin{tabular}{|c|c|c|c|c|}
\hline $\begin{array}{l}\text { Learning } \\
\text { Styles }\end{array}$ & Disciplines & Personality & Learning Motivators & Game Genres \\
\hline $\begin{array}{c}\text { Divergers } \\
\text { (Reflectors)* }\end{array}$ & $\begin{array}{l}\text { Dramatic Arts, History, Eng- } \\
\text { lish, Philosophy, Politics, } \\
\text { Communications, Econom- } \\
\text { ics, Psychology, Anthro- } \\
\text { pology, Computer Games } \\
\text { Development }\end{array}$ & High Neuroticism & $\begin{array}{l}\text { Observational Situations, Time } \\
\text { for Contemplation, Thinking } \\
\text { things through before acting, De- } \\
\text { tailed Researching and Analysis, } \\
\text { No strict deadlines, Can freely } \\
\text { exchange opinions without threat } \\
\text { of backlash. }\end{array}$ & $\begin{array}{l}\text { Strategy games (featuring } \\
\text { world-building real-time } \\
\text { strategy-not too pressured) }\end{array}$ \\
\hline $\begin{array}{l}\text { Assimilators } \\
\text { (Theorists)* }\end{array}$ & $\begin{array}{l}\text { Geography, Economics, } \\
\text { Mathematics, Biochemistry, } \\
\text { Chemistry, Physics }\end{array}$ & $\begin{array}{l}\text { Low Neuroticism } \\
\text { High Extraversion }\end{array}$ & $\begin{array}{l}\text { Can understand educational } \\
\text { content in the context of a larger } \\
\text { system: } \\
\text { - Methodical exploration } \\
\text { - Hypothesising and Test- } \\
\text { ing } \\
\text { - Intellectually Challeng- } \\
\text { ing } \\
\text { - Highly Structured } \\
\text { - Extra-curriculum knowl- } \\
\text { edge }\end{array}$ & $\begin{array}{l}\text { Adventure games (platform- } \\
\text { ers, puzzles, quizzes that } \\
\text { reward trial and error) }\end{array}$ \\
\hline $\begin{array}{c}\text { Convergers } \\
\text { (Pragmatists)* }\end{array}$ & $\begin{array}{l}\text { Nursing, Engineering, Com- } \\
\text { puter Science }\end{array}$ & $\begin{array}{l}\text { High Openness, High } \\
\text { Extraversion }\end{array}$ & $\begin{array}{l}\text { Relevant links with real world } \\
\text { issues, problems and their own } \\
\text { lives. Techniques with practical } \\
\text { advantages, Apprenticeships and/ } \\
\text { or on the job training, Imitation, } \\
\text { Immediate implementation, Get- } \\
\text { ting on with the job }\end{array}$ & $\begin{array}{l}\text { Process-oriented games (fea- } \\
\text { turing life simulation, role- } \\
\text { playing and online social } \\
\text { environments) }\end{array}$ \\
\hline $\begin{array}{l}\text { Accomodators } \\
\text { (Activists)* }^{*}\end{array}$ & $\begin{array}{l}\text { Business, Finance, Architec- } \\
\text { ture, Accounting, Law }\end{array}$ & $\begin{array}{l}\text { High Openness, High } \\
\text { Conscientiousness, } \\
\text { High Extraversion, } \\
\text { High Agreeableness }\end{array}$ & $\begin{array}{l}\text { Challenges, Relevant competi- } \\
\text { tive teamwork, Variety and ex- } \\
\text { citement, Leadership and high } \\
\text { visibility tasks, Brainstorming } \\
\text { sessions, Entrepreneur }\end{array}$ & $\begin{array}{l}\text { Action games (tapping into } \\
\text { on-rail and achievement } \\
\text { oriented score ladders) }\end{array}$ \\
\hline
\end{tabular}

related chunks of information in realistic situations and problem spaces. Indeed, the premise of this chapter supports the many studies that have concluded that experiential learning is a fundamental human process (Kolb, 1984).

The divergence of game genre between disciplines is a product of differing learning styles that correlate with personality and career/study choice of individuals. The goal of all games is to teach the player. The chunks within the game are identified by the player and thus 'speak' to their preferred way of learning. In addition, these chunks must be presented as interrelated facts and delivered through the appropriate game mechanics. For example, Divergers learn best through observation and analysis of underlying cause and effect; strategy games deliver a game mechanic which best fits this requirement. Furthermore, Divergers better assimilate knowledge when it is presented as interconnected material related to the bigger picture, rather than unrelated chunks which are perceived as merely information. In contrast, the more extraverted learning styles prefer to control what knowledge chunks contain and determine how they are related.

To this end, Table 4, identifies how learning styles could be best matched in terms of gamegenre and game mechanics.

The classification of motivators in Table 4 also relates directly to the game genre and thus game mechanics. Motivation during game play is linked to Flow Theory (Csikszentmihalyi, 1975) which 
describes how the game challenge at hand must not be too difficult or too easy to keep the player interested. For a student to attain flow in a learning activity a balance between external complexity and the internal mental model of the learner must be found. This internal mental model is a direct result of how the game chunks the content and presents it to the player. As such, game genre and game mechanics are most relevant in delivering game content to achieve flow for different learning styles whether it be for an individual or an entire student cohort within a discipline.

In developing this overview, we also understand that students are presented with a wide diversity of teaching and learning activities at tertiary institutions which may require the use of a variety of game genres to best deliver content. As such, the typology presented here relates to the fundamental learning activities and professional situations encountered by differing student cohorts. For example, although nurses are required to learn mathematics (the domain of the Assimilator), their principle assignment is in dealing with and managing people. Having said this, it is also worth considering that subjects which are crossdisciplinary require different teaching approaches across student cohorts and appropriate games and pedagogy needs to match learning styles. For example, a practical role-playing based game in which students measure and administer medicines for learning mathematics would be more suitable than mathematical puzzles for nurses.

\section{SOME FINAL WORDS}

Educators who integrate knowledge about their students' learning styles with their use of computer games in the classroom can greatly improve student motivation in the use and educational effectiveness of the games. Narrowing the focus of which games are the most appropriate further assists teachers in creating a more student-centred classroom.
The first stage in implementing learning style-based serious games is in understanding disciplinary characteristics by either conducting the LSI questionnaire in class or referring to previous studies. Following this it is necessary to understand the nature of the learning objectives with the discipline in order to select and/ or develop an effective and motivational game. Finally, educators should assess their current instructional methods and evaluate them against recommendations from learning style literature to develop and adapt them to conform.

This chapter has identified the need for both empirical and conceptual clarity on the most effective way to use games to teach to ensure maximised learning outcomes. The scope and focus of contributes to the understanding of Serious Games by clarifying and adding precision to the acceptance of particular games for motivating particular student cohorts. This chapter also provides best practice advice to developers to assist them in creating maximally motivating games. Our intention has been to provide concrete examples that serve as take-away guidance for developers and educators alike. The authors bring backgrounds to the book from software engineering education and social psychology education and understand the need to communicate clearly to the target audience of practitioners, researchers and educators in a diverse range of fields.

The pedagogical reasons for deploying computer game-based learning is that they have the potential to act as experiential, problem-based and collaborative environments which include characteristics of constructivist learning opportunities. However, it should not be assumed that games always motivate because learning style and personalities are diverse across disciplinary study areas and as such differing student cohorts are motivated and engaged through a variety of differing pedagogical activities.

Through the presentation of the typology herein, we suggest a targeted approach to the use of computer games in the classroom. If the 
games are to motivate the students then they must address the learning style and personality needs within different disciplines. Only then can we be sure we are using the correct match of effective teaching motivations and principles with student needs and not relying solely on the computer game as a new medium to inherently talk to learners.

\section{REFERENCES}

Aarseth, E., Smedstad, S. M., \& Sunnana, L. (2003). A multi-dimensional typology of games. In M. Copier \& J. Raessens (Eds.), Proceedings of the First Annual Digital Games and Research Association Conference, Utrecht, 4-6 November, (pp. 48-53).

Baltra,A.(1990). Language learning through computeradventuregames.Simulation \& Gaming,21(4), 445-452. doi:10.1177/104687819002100408

Bartle, R.(2005). Virtual worlds: Why people play. InAlexander, T.(Ed.), Massivelymultiplayergame development (2nd ed., pp. 3-18). MA: Charles River Media.

Biglan, A. (1973). The characteristics of subject matter in different academic areas. The Journal of Applied Psychology, 57, 195-203. doi:10.1037/ h0034701

Bransford, J. D., Sherwood, R. D., Hasselbring, T. S., Kinzer, C. K., \& Williams, S. M. (1990). Anchored instruction: Why we need it and how technology can help. In Nix, D., \& Spiro, R. J. (Eds.), Cognition education, and multimedia: Exploringideas in high technology (pp. 115-141). Hillsdale, NJ: Lawrence Erlbaum Associates.

Brauer, J., \& Delemeester, G. (2001). Games economists play: A survey of non-computerized classroom-games for college economics. Economic Surveys, 15, 221-236. doi:10.1111/14676419.00137
Busato, V., Prins, F. J., Elshout, J. J., \& Hamaker, C. (2000). Intellectual ability, learning style, personality, achievement motivation and academic success of psychology students in higher education. Personality and Individual Differences, 29(6), 1057-1068. doi:10.1016/S01918869(99)00253-6

Chase, W. G., \& Simon, H. A. (1973). Perception in chess. Cognitive Psychology, 4, 55-81. doi:10.1016/0010-0285(73)90004-2

Chong, Y., \& Wong, M. (2005). The impact of learning styles on the effectiveness of digital games in education. Symposium on Information Technology in Education. Malaysia, KDU College, Patailing Java.

Csikszentmihalyi, M. (1975). Play and intrinsic rewards. Journal of Humanistic Psychology, 15, 41-63. doi:10.1177/002216787501500306

de Byl, P. (2010). The learning styles of computer game development students and implications for teaching style. Game Education Review, 1.

DeGroot, A. (1965). Thought and choice in chess. The Hague: Mouton.

Egan, D. E., \& Schwartz, B. J. (1979). Chunking in recall of symbolic drawings. Memory \& Cognition, 7, 149-158. doi:10.3758/BF03197595

Egenfeldt-Nielsen, S., Smith, J. H., \& Tosca, S. P. (2008). Understanding video games: The essential introduction. New York: Tayor \& Francis.

Feldman, S. (1974). Escape from the doll's house. New York: McGraw-Hill.

Garris, R., Ahlers, R., \& Driskell, J. E. (2002). Games, motivation and learning: A research and practice model. Simulation \& Gaming, 33(4), 441-467. doi:10.1177/1046878102238607

Gee, J.P. (2007). Learning and games. Digital Media and Learning, 21-40. 
Goldberg, L. R. (1990). An alternative description of personality: The big-five factor structure. Journal of Personality and Social Psychology, 59, 1216-1229. doi:10.1037/0022-3514.59.6.1216

Honey, P., \& Mumford, A. (1982). Manual of learning styles. London: P. Honey.

$\mathrm{Hu}$, M. (2004). The relationship between big five personality traits: Learning motivations and learning performance of the hospitality students in Taiwan. Paper presented at the 10th Annual Asia Pacific Tourism Association (APTA) Conference, July 4-7 2004, Nagasaki, Japan.

Kellar, M., Watters, C., \& Duffy, J. (2005). Motivational factors in game play in two user groups. DIGRA 2005: Changing Views-Worlds in Play. Authors \& Digital Games Research Association.

Kolb,D.A. (1981). Learning styles and disciplinary differences. A.W. Chickering (Ed.), The modern American college. San Francisco: Jossey-Bass.

Kolb,D.A., \& Kolb,A.Y.(2005). The Kolblearning style inventory-version 3.1. Case Western Reserve University, HayGroup.

Lesgold, A. (1988). Toward a theory of curriculum for use in designing intelligent instructional systems. In Mandl, H., \& Lesgold, A. (Eds.), Learning issues for intelligent tutoring systems (pp. 114-137). New York: Springer-Verlag.

Lindblom-Ylanne, S., \& Trigwell, K. (2006). How approaches to teaching are affected by discipline and teaching context. [Routledge.]. Studies in Higher Education, "', 31.

Malone, T.W. (1981). Toward a theory of intrinsically motivating instruction. Cognitive Science: A Multidisciplinary Journal, 5(4), 333-369.

Malone, T. W., \& Lepper, M. R. (1987). Making learning fun: A taxonomy of intrinsic motivations for learning. In Snow, R. E., \& Farr, M. J. (Eds.), Aptitude, learning and instruction: III. Conative and affective process analyses (pp. 223-253). Hillsdale, NJ: Erlbaum.
McGonigal, J. (2007). Why I love bees: A case study in collective intelligence gaming. Digital Media and Learning, 199-227.

Miller, G. A. (1956). The magical number seven, plus or minus two: Some limits on our capacity for processing information. Psychological Review, 63, 81-97. doi:10.1037/h0043158

Papert, S.(1980). Mindstorms: Children, computers and powerful ideas. Cambridge: ACM.

Prensky, M.(2000).Digital game-based learning. McGraw-Hill Companies.

Prensky, M. (2005). Computergames and learning: Digital game-based learning. In Raessens, J., \& Goldstein, J. (Eds.), Handbook of computer game studies. Cambridge, MA: MIT Press.

Rapeepisarn, K., Wong, K. W., Fung, C. C., \& Khine, M. S. (2008). The relationship between game genres, learning techniques and learning styles in educational computer games. Technologies for E-Learning and Digital Entertainment, Third International Conference, Edutainment 2008, Nanjing, China, Springer-Verlag.

Rigby, C. S., \& Prysbylski, A. K. (2009). Virtual worlds and the learner hero: How today's video games can inform tomorrow's digital learning environments. Theory and Research in Education, 7(2), 214-223. doi:10.1177/1477878509104326

Rosser, J. C. Jr, Lynch, P. J., Cuddihy, L., Gentile, G. A., Klonsky, J., \& Merrell, R. (2007). The impact of video games on training surgeons in the 21st century. Archives of Surgery, 142(2), 181-186. doi:10.1001/archsurg.142.2.181

Shih, C., \& Gamon, J. (2001). Web-based learning: Relationships among student motivation, attitude, learning styles and achievement. Journal of Agricultural Education, 42(4). doi:10.5032/ jae.2001.04012 
Tychsen, A., Hitchens, M., \& Brolund, T. (2008). Motivations for play in computer role-playing games. Future play: Research, play, share. Toronto, Ontario.

Vermunt, J. D. (2005). Relations between student learning patterns and personal and contextual factors and academic performance. [Netherlands: Springer]. Higher Education, 49, 205-234. doi:10.1007/s10734-004-6664-2

Werner, L., Hanks, B., \& McDowell, C. (2004). Pair-programming helps female computer science students. ACM Journal of Educational Resources in Computing, 4(1), 1-8.

Whitton, N. (2007). Motivation and computer game based learning. ASCILITE 2007. Singapore.

Wolf, M. J. P., \& Baer, R. H. (2002). Genre and the video game. In The medium of the video game (pp. 114-134). Austin: University of Texas Press.

\section{KEY TERMS AND DEFINITIONS}

Game Mechanics: The fundamental rules that define the play, objective and challenge to which the player works in order to win; common mechanics include taking turns, random chance, capture and eliminate, bidding in an auction, racing the clock and so on.

Genre: Categories of different types within the same medium; computer games genres class games according to the actions and objectives set out for the player to reach a win our outcome such as action, adventure, strategy and role-playing games. Some games are characterized by the visual perspective of the player in relation to the character in the game, such as first-person shooter games.

LearningActivity: Exercises and experiences designed by teachers to facilitate learning; learning activities often match a learning style.

Learning Style: Different ways students processes information and thereby learn optimally; learning styles include concrete experience, reflective observation, abstract conceptualization and active experimentation.

Motivation: The initiation of behavior for achieving a goal, motivation can be achieved either from within the learner or from outside the learner by a stimulus such as a teacher or a game.

Participation: Involvement of a person in an activity either with others or in an experience designed by others.

Personality: The combination of characteristics that define the way the person thinks and behaves; it is believed that all people have every type of personality trait but that some have low levels and others high levels on each trait.

Serious Game: Serious games are games that serve a purpose beyond leisure; serious games are designed to be entertaining and to educate or demonstrate, persuade or communicate. 